\title{
The Study of Polysemy in the Framework of Cognitive Semantics in Azerbaijani Turkish
}

\author{
Yousef Hazrati $^{1}$, Fateme Yousefirad ${ }^{1}$, Belghis Rovshan ${ }^{1} \&$ Mohammad Reza Ahmadkhani ${ }^{1}$ \\ ${ }^{1}$ Department of Linguistics and Foreign Languages, Payame Noor University, Tehran, Iran \\ Correspondence: Yousef Hazrati, PhD student, Department of Linguistics and Foreign Languages, Payame Noor \\ University, P. O. Box 19395-3697, Tehran, Iran. E-mail: Hazratiyousef@gmail.com
}

Received: August 18, 2016

Accepted: September 10, 2016 Online Published: September 23, 2016

doi:10.5539/ijel.v6n5p130

URL: http://dx.doi.org/10.5539/ijel.v6n5p130

\begin{abstract}
The aim of the present study is to investigate the role of conceptual metaphor in the polysemy of the visual verb of /baxmaq/ (look) in Azerbaijani Turkish within the framework of cognitive semantics. The research method is a descriptive - analytic and the study tries to present the various meanings of the verb. To achieve this goal, the linguistic data was gathered by using Azerbaijani Turkish dictionaries, books, magazines, newspapers, and one of the authors' linguistic intuitions. The findings indicate that for visual verb /baxmaq/ there are 19 senses with regard to its classification and abstracting away of contextual variations. They also show that the polysemy is a systematic phenomenon and factor such as metaphor and metonymy are crucially involved in the formation and description of polysemy and this makes broad meaning and eventually leads to polysemy of verb. In this way, semantic extensive network of verb is formed and on the other hand, it is claimed that metaphor has stronger role than metonymy in the formation of polysemy and usage of verb in the different context. The findings also show that polysemy is not randomly and forms based on our experiences of different concepts and the meanings of verbs are different from each other because they are understood from different ways.
\end{abstract}

Keywords: Azerbaijani Turkish, cognitive semantics, polysemy, metaphor

\section{Introduction}

Cognitive linguistics has its roots in the linguistic discussions as well as the recent cognitive sciences which appeared in 1960's and 1970's, particularly, in investigating categorization and conceptualization in human's mind and Gestalt psychology (Evans \& Green, 2006, p. 6). According to this approach, language knowledge is not separate from thinking and cognition. Cognitive semantics is one of the most important topics in cognitive linguistics and studying it is considered as one of the most basic discussions in this domain. The terminology of cognitive semantics was proposed for the first time by Lakoff.

One of the most basic parts of the study of cognitive semantics is the investigation of metaphor from a cognitive point of view which was first proposed by Lakoff \& Johnson (1980) as the "Theory of Conceptual Metaphor" or the "Theory of Cognitive Metaphor" where in metaphor is not only a stylistic feature of language, but thought and mind have a metaphorical nature as well. They emphasize that metaphor is not necessarily a language tool to convey thought, but it is a way of thinking about different things. In this theory, conceptual structures are shaped based on mappings between cognitive areas. By mapping, we mean the matching of two cognitive domains which are close to each other through metaphor. They have also concluded that abstract concepts in human's mind are organized via using concrete concepts which means that language clarifies the issues we express, or understand abstract concepts based on concrete concepts (Lakoff \& Johnson, 2003, p. 28).

One of the important concepts in cognitive semantics is polysemy which means using a single language element in different meanings. Cognitive semantics experts believe that polysemy is completely systematic and this is the human cognition that monitors the type and extent of polysemy. Therefore, the study of polysemy from a cognitive semantics point of view makes it possible to understand the mechanisms of human mind as well as the power of human cognition.

In most of the languages, particularly, in Azerbaijani Turkish, polysemy and the metaphorical words and expressions are commonly used in order to convey the internal experience and understand abstract concepts. In 
this language, there are so many words and expressions which possess different meanings. In other words, they are polysemic and metaphorical. Among these words are the visual verbs which in addition to showing the action of seeing, according to their situations, are used to express comprehension, understanding, knowledge, light, wisdom, etc. In this language, the visual verb /baxmaq/ (look) is considered as a visual verb which in addition to indicating its real meaning, is used in order to express the internal experience, understand abstract concepts, and convey different aspects of cognition.

With regard to the aforementioned issues, it can be argued that polysemy and metaphor are of great importance in languages and the studies related to this area can, in fact, enrich linguistic research. Most of the research studies on polysemy and metaphor, which have been conducted in Iran, have solely focused on investigating metaphor and its related subjects in the Persian and some of these studies have only focused on one aspect of metaphor. Considering the fact that there is no research studies in Iran about polysemy and metaphor in Azerbaijani Turkish, this study, aims to investigate the metaphor and polysemy of the visual verb /baxmaq/ (look) in Azerbaijani Turkish in a cognitive semantics approach by providing answers for the following research questions:

1) What is the polysemy and metaphorical status of the visual verb /baxmaq/ (look)?

2) What are the prototypical and marginal meanings of the visual verb /baxmaq/ (look) form a cognitive point of view?

3) What are the role of cognitive mechanisms, such as different conceptual metaphors and metonymy in the polysemy of the visual verb /baxmaq/ (look)?

\section{Research Background}

Since in Azerbaijani Turkish there has been no study about polysemy of visual verbs, thus here has been mentioned some of studies about polysemy of verbs in Persian and other languages.

Viberg (1981) made some efforts in order to examine sensory verbs in English, Turkish, Indian, Persian, and Japanese languages. In this way, he introduced three general components for the five senses based on which he shaped the investigation and analysis of the sensory verbs. He also proposed a model of polysemy with regard to the role of the senses. The studies conducted on visual verbs by Sweetser (1990) also indicated that the most common target areas for the visual verbs are knowledge, wisdom, and mental vision. He brings some examples from English, Greek, Latin, and Irish and shows that the transfer of visual verbs to abstract areas is not solely limited to English language, but it is related to most of languages. This kind of transfer belongs to a larger system which is called the metaphor of "the mind as the body". He claims that this metaphor is probably motivated through the correlation between the external experiences and the internal cognitive states and excitements, but this correlation cannot explain the observed patterns of polysemy and semantic change by itself. Therefore, there is a need for a more complete and complex mapping and representation which is beyond correlation (Sweetster, 1990, p. 28).

In a comprehensive study titled as "Polysemy and Metaphor in Perceptive Verbs: An interlanguage study", Ibarretxe-Antunano (1999) focused on the analysis of polysemy and metaphor in the semantic area of perceptive verbs and examined how polysemic metaphorical structures occur between the area of physical perceptions and other conceptual areas in English, Basque, and Spanish and pointed out that perceptive verbs transfer both physical and metaphorical meanings, which are mostly interlanguage in a more extensive level. Sgöstrom (1998) also investigated visual verbs' metaphor and polysemy according to the four categories of visual perception, experiencer features, experienced features, and perception cause in Swedish language and showed that polysemy and metaphorical use of visual words in Swedish are not only related to verbs, but they are also related to nouns and adjectives. Nechybova (2008) also has specified his study to the investigation of conceptual metaphors, particularly, the conceptual metaphor of "from seeing to understanding" in English language. After examining the verb of seeing in that study, he stated that this verb possesses nine main meanings.

Yousefi Rad (2008) examined the propositions of the Persian in a cognitive linguistics framework. By analyzing spatial propositions in Persian which were extracted from Persian databases, she showed that despite the traditional grammar, using propositions is very structured and the spatial meaning of propositions which is considered as the primary meaning, is related to its other meanings via the cognitive mechanisms, particularly metaphor and metonymy. This phenomenon leads to the semantic expansion of the spatial propositions in Persian and in this way; the wide semantic network of propositions is formed. Adopting a cognitive approach, Fayyazi (2008) also investigated polysemy in Persian and after presenting a new typology for semantic changes, indicated the role of metaphor in creating new meanings, and considered its regular performance as a structured 
system in the area of words. Likewise, Sharifi (2009) examined the relationship between the polysemy of the simple verb $(\mathrm{fall})$ in Persian and its cognitive elements. In this study, she investigated the polysemy of the simple verb (fall) based on certain concepts, such as categorization, prototype, image schemas, and radical categories.

Pour Ebrahim et al. (2012) investigated the concept of "insight" in the framework of the contemporary theory of metaphor in the language of the Quran in the area of cognitive semantics and stated that the metaphors of "knowing is as seeing/ hearing" has been frequently and effectively used in the language of the Quran. Soltani Kofrani (2012) examined the polysemy of simple motion verbs in Persian in a cognitive linguistics framework. Mousavi et al. (2014) also examined the word "seeing" from a semantic perspective in order to demonstrate how the meaning of some words exist in humans' daily experiences and background knowledge. They aimed to find the meaning frameworks of the verb "seeing" and state the relationships and differences between the verb "seeing" and other synonymous verbs, such as "observe", "watch", "look", and etc.

\section{Theoretical Framework}

Cognitive semantics was first proposed by Lakoff (1980a) who introduced a point of view which attracted the attention of many semantics experts. According to this point of view, language knowledge is not separate from thinking and cognition and the language semantics is substantially based on cognition. This point of view was introduced through six main characteristic which are listed below (Allwood \& Gordenfors, 1998, p. 21):

1) Meaning is conceptualization in a cognitive model (not truth conditions in possible worlds).

2) Cognitive models are mainly perceptually determined (meaning is not independent of perception).

3) Semantic elements are based on spatial or topological objects (not symbols that can be composed according to some system of rules).

4) Cognitive models are primarily image-schematic (not propositional). Image-schemas are transformed by metaphoric and metonymic operations (which are treated as exceptional features in the traditional view).

5) Semantics is primary to syntax and partly determines it (syntax cannot be described independently of semantics).

6) Concepts show prototype effects (instead of following the Aristotelian paradigm based on necessary and sufficient conditions).

In cognitive semantics there are some concepts that most important of them are mentioned below:

\subsection{Metaphor}

Metaphor is very important in the cognitive semantics and the study of metaphor is one of the most basic issues in cognitive semantics. Lakoff \& Johnson (1980) defined metaphor as the relationship between two semantic areas where one semantic area is stated based on the other; that is one abstract object is understood and experienced based on a more tangible object. For example, the semantic area of time is formulated based on the semantic area of place and motion. Accordingly, the metaphorical phrase "the new year is rapidly approaching us" can be understood in this way.

According to Lakoff \& Johnson (1980), the contemporary theory of metaphor is based on two hypotheses: 1) Metaphor is not specified to literature and is used in everyday use of language and 2) Metaphor is not basically a language phenomenon, but it has its roots in human's conceptual system. In this theory, metaphor is divided into three types of directional, ontological, and structure. In directional metaphors, a general system of concepts is organized by considering some concepts from another system and the individual provides a spatial direction to the abstract concept. Ontological metaphors provide the individual with this opportunity to take some parts of his/ her experiences and treat them like separate components or homogenous materials. In structural metaphors, the exact conceptual structure of the source is restored into the abstract conceptual structure of target area and some features of the source are highlighted, while others remain hidden.

\subsection{Metonymy}

Lakoff \& Johnson (2003) believe that there is a difference between metonymy and metaphor in the sense that in metonymy an object is used in order to refer to another object in a determined and clear context. For example, it is possible for the waiter of a restaurant to use "He is a Spaghetti" in order to refer to a person who has ordered Spaghetti. In this phrase, metonymy has been used. In a relation which is based on metonymy, two elements are always in a specific relationship with each other. The most important difference between metaphor and metonymy is in that two mental areas are involved in metaphor, while there is only one active mental area in metonymy. 


\subsection{Polysemy}

Goddard (2000) states that polysemy is a situation where a single word has several meanings. Taylor (1995) believes that polysemy is the association of two or several meanings all of which are related to a single language form. In other words, polysemy is a phenomenon in which a single language unit possesses several separate meanings that are related to each other. Cognitive linguists believe that polysemy is not solely related to the meaning of words. According to this point of view, polysemy exists in various parts of language, such as words, morphemes, and grammar. Lakoff (1980b) also maintains that there are three important sources in the creation of polysemy which are listed below: Metaphor, 2) Metonymy, and 3) Transformation of image schemas.

\section{Methodology}

The present study is a descriptive investigation which aims at exploring different meanings of the visual verb /baxmaq/ (look) in Azerbaijani Turkish according to the cognitive semantics approach and finally providing a description of the relationships that exist among these meanings as well as the causes of these relations. This study is a descriptive-analytic and tries to present the various meanings of the verb. To achieve this goal, the linguistic data was gathered by using Azerbaijani Turkish dictionaries, books, newspapers, magazines, and the author's linguistic intuition.

\section{Data Analysis}

The visual verb which is going to be investigated in this study is /baxmaq/ (look) whose primary meaning (prototype) is "to see something by means of eyes". Bezadi (1997) said that its meaning is as below:

Nəzərini bir şeyə tikmək. (Pay attention to something) x other meanings, and most importantly, this is the meaning that cannot be expressed via other verbs. By studying of various contexts of verb from books, newspapers, magazines, dictionaries, and other publications in Azerbaijani Turkish 140 usages of this verb was extracted and 19 senses, one prototype and 18 peripheral meaning groups after classification and abstracting away of contextual variations were presented. The prototype of the verb /baxmaq/ (look) is: Looking at something or someone to recreation, enjoyment and entertainment.

Eighteen peripheral meaning groups of the visual verb /baxmaq/ (look) are as follows:

1) Qaramaq (take care), göz olmaq (watch), güdmək (lay ambush), qorumaq (guard), güdək (look after)

2) Müayenə etmək (treat), müayenə etmək (examine), tumarlamaq (heal), qirmalamaq (nursing), arqamaq (consider), arqamaq (check)

3) Airamaq (manage), başçeleq etmək (lead), hidayət etmək (conduct), başçeleq etmək (direct)

4) Max vermək (pay attention), saimaq (regard), təmərküz etmək (concentrate)

5) Tabi olmaq (being subordinate), qolaq asmaq (obey), izləmək (follow)

6) Qimətə gurtarmaq (cost)

7) Açilmaq (open), dönmək (return), qayitmaq (come back)

8) Axtarmaq (search), araşdırmaq (explore), araşdirmaq (investigate), axtarrişmaq (ask about)

9) Mütaliə etmək (study), oxumaq (read), təhsil etmək (educate), oirənmək (learn), məşğul olmaq (engage in)

10) Ibrət almaq (take lesson), ibrət almaq (get advice), döyüq düşmmək (being conscious of), öirənmək (learn), ifrət götümək (advice)

11) Fikir vermək (think), təsəvvürünə gətirmək (imagine), qimət ləndirmək (consider), fərz etmək (assume), fərz etmək (suppose)

12) Diqqət eləmək (make precise), öiçəmək (measure)

13) Nəzərə almaq (take into account), hesab etmək (value), saimaq (emphasize)

14) Müzakirə etmək (negotiate), danişmaq (talk), görubşub danişmaq (speak)

15) Xitmət etmək (serve), iş görmək (work)

16) Bağli olmaq (depend on), əlaqedar olmaq (interest in)

17) Fala baxmaq (soothsay), qabaği görmək (predict), sanamaq (guess)

18) Göznəmək (wait for), gözləmək (wait)

To facilitate the study of meanings of the visual verb /baxmaq/ (look) we choose a verb as a pattern from each group and bring a sentence for each of them and then investigate the metaphorical of them. 


\begin{tabular}{ll}
\hline Vəhid hər cün atasina baxar. & Vahid everyday serves to his father. \\
\hline Bü iş sənə baxir. & This work depends on you. \\
Çitaba baxdi. & He soothsays. \\
Baxiram həsən gələ & I wait for Hasan to come. \\
O baxir sənin fərasətinə. & That is subordinate to your acumen \\
Mənə baxmir. & He does not pay attention to me. \\
Bura çim baxir? & Who manages here? \\
Məclisdə hansi məsələrə baxacaqlar? & Which issue will negotiate in parliament? \\
Xəstəyə hansi həkim baxir? & Which doctor treats the patient? \\
Xəstəyə yaxşi bax & Take good care of the patient \\
Mən ona bir alim kimi baxiram. & I take him into account as scientist. \\
Bax ayaqivə nəcasətə qorma. & Be careful do not put your feet on filth. \\
Baxarsan xoşüna gəlsə agarsan. & Do you think if he likes you will buy? \\
Yoldaşlarina bax ozünü dözələt. & Take a lesson from your friends and make yourself right. \\
Gli kitaba baxmir. & Ali does not study the book. \\
Ggər yaxşi baxson onu taparsan. & If you search well you will find it. \\
Evin pəncərəri hitə baxir. & The windows of house are opening to yard. \\
Mənə on min tümənə baxdi & It was cost ten Tomans to me. \\
\hline
\end{tabular}

With regards to prototype and peripheral meanings, semantic network of verb /baxmaq/ (look) is as follow:

Diagram (1) semantic network of the visual verb /baxmaq/ (look)

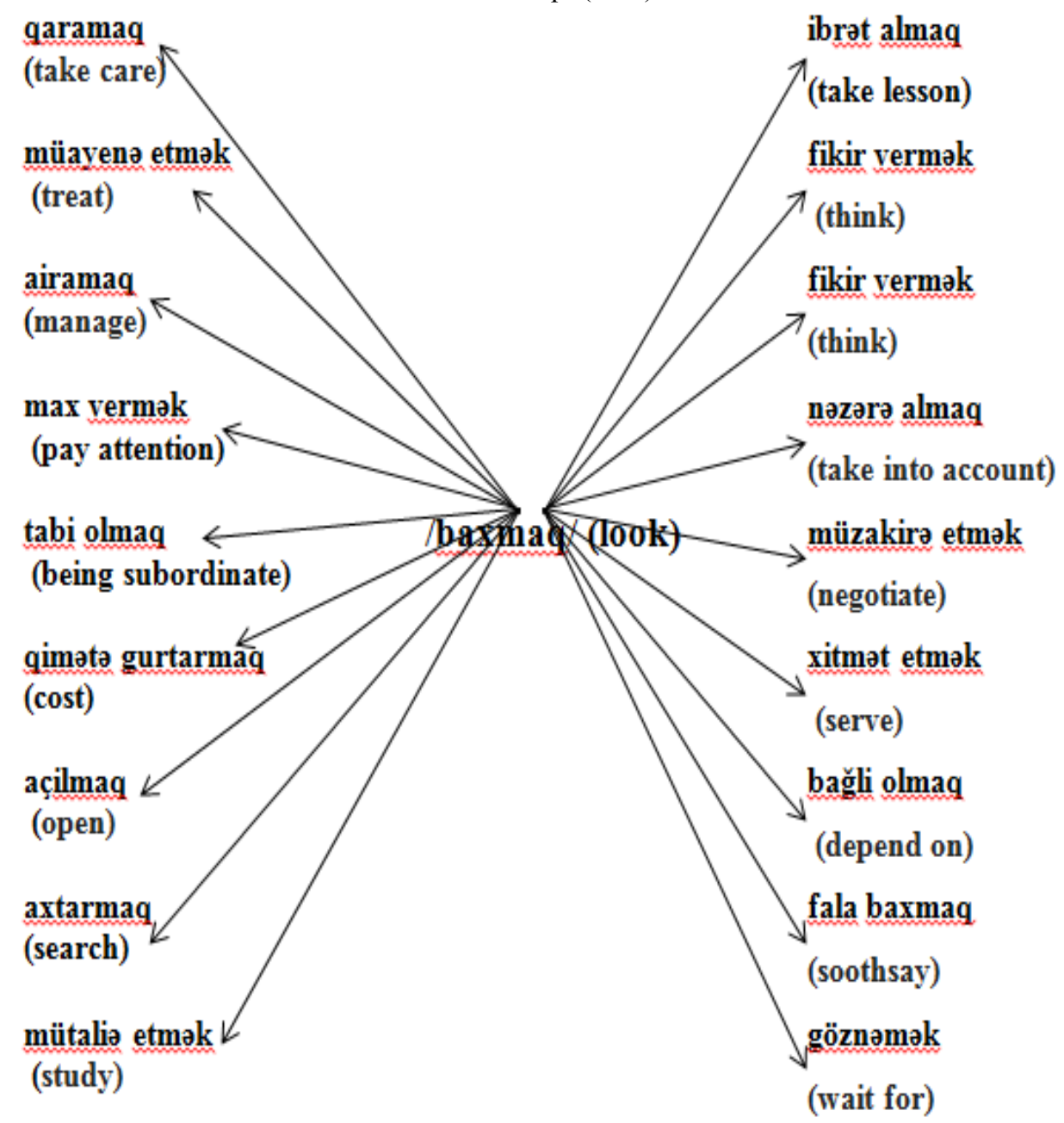

The peripheral meanings of the visual verb /baxmaq/ (look) along with the context in which they are used are as follow: 


\begin{tabular}{|l|l|}
\hline 1) "baxmaq xitmət etmək dir" & "Looking is serving" \\
\hline Vəhid hər cün atasina baxar. & Vahid everyday serves to his father. \\
\hline 2) "baxmaq bağli olmaq dir" & "Looking is depending on" \\
\hline Bü iş sənə baxir. & This work depends on you. \\
\hline 3) "baxmaq tabi olmaq dir" & "Looking is being subordinate" \\
\hline O baxir sənin fərasətinə & That is subordinate to your acumen \\
\hline 4) "baxmaq max vermək dir" & "Looking is paying attention" \\
\hline Mənə baxmir & He does not pay attention to me. \\
\hline 5) baxmaq airamaq dir & "Looking is managing" \\
\hline im baxir? ç Bura & Who manages here? \\
\hline 6) "baxmaq müzakirə etmək dir" & "Looking is negotiating" \\
\hline Məclisdə hansi məsələrə baxacaqlar? & Which issue will negotiate in parliament? \\
\hline 7) "baxmaq hesab etmək dir" & "Looking is taking into account" \\
\hline Mən ona bir alim kimi baxiram & I take him into account as scientist. \\
\hline 8) "baxmaq fikir vermək dir" & "Looking is thinking" \\
\hline Baxarsan xoşüna gəlsə agarsan. & Do you think if he likes you will buy? \\
\hline 9) "baxmaq ibrət almaq dir" & "Looking is taking lesson" \\
\hline Yoldaşlarina bax ozünü dözələt. & Take a lesson from your friends and make yourself right. \\
\hline 10) "baxmaq acilmaq dir" & "Looking is opening" \\
\hline Evin pəncərəri hitə baxir. & The windows of house are opening to yard. \\
\hline 11) "baxmaq qimətə gurtarmaq dir" & "Looking is costing" \\
\hline Mənə on min tümənə baxdi & It was cost ten Tomans to me. \\
\hline
\end{tabular}

Table 1. The visual verb /baxmaq/ (look)

\begin{tabular}{llll}
\hline row & \multicolumn{2}{c}{ source domain } & target domain \\
\hline 1 & /baxmaq/ & (look) & /xitmət etmək/ (serve) \\
2 & /baxmaq/ & (look) & /müzakirə etmək/ (negotiate)/ \\
3 & /baxmaq/ & (look) & /airamaq/ (manage) \\
4 & /baxmaq/ & (look) & /bağli olmaq/ (depend on) \\
5 & /baxmaq/ & (look) & /max vermək/ (pay attention) \\
6 & /baxmaq/ & (look) & /nəzərə almaq/ (take into account) \\
7 & /baxmaq/ & (look) & /fikir vermək/ (think) \\
8 & /baxmaq/ & (look) & /ibrət almaq/ (take lesson) \\
9 & /baxmaq/ & (look) & /açilmaq/ (open) \\
10 & /baxmaq/ & (look) & /tabi olmaq/ (being subordinate) \\
11 & /baxmaq/ & (look) & /qimətə gurtarmaq/ (cost) \\
\hline
\end{tabular}

Most of the peripheral meanings of the visual verb /baxmaq/ (look) are due to the conceptual metaphor of structural type. In this way that the source domain that is an abstract concept is understood by the target domain that is a real concept. For example, "Looking is thinking" means that thinking is an abstract verb is understood by verb seeing that is real than thinking. According to the peripheral meanings and cognitive mechanisms, such as conceptual metaphors and metonymy the proposed semantic network of visual verb /baxmaq/ (look) is as follow: 
Diagram (2) the proposed semantic network of visual verb /baxmaq/ (look)

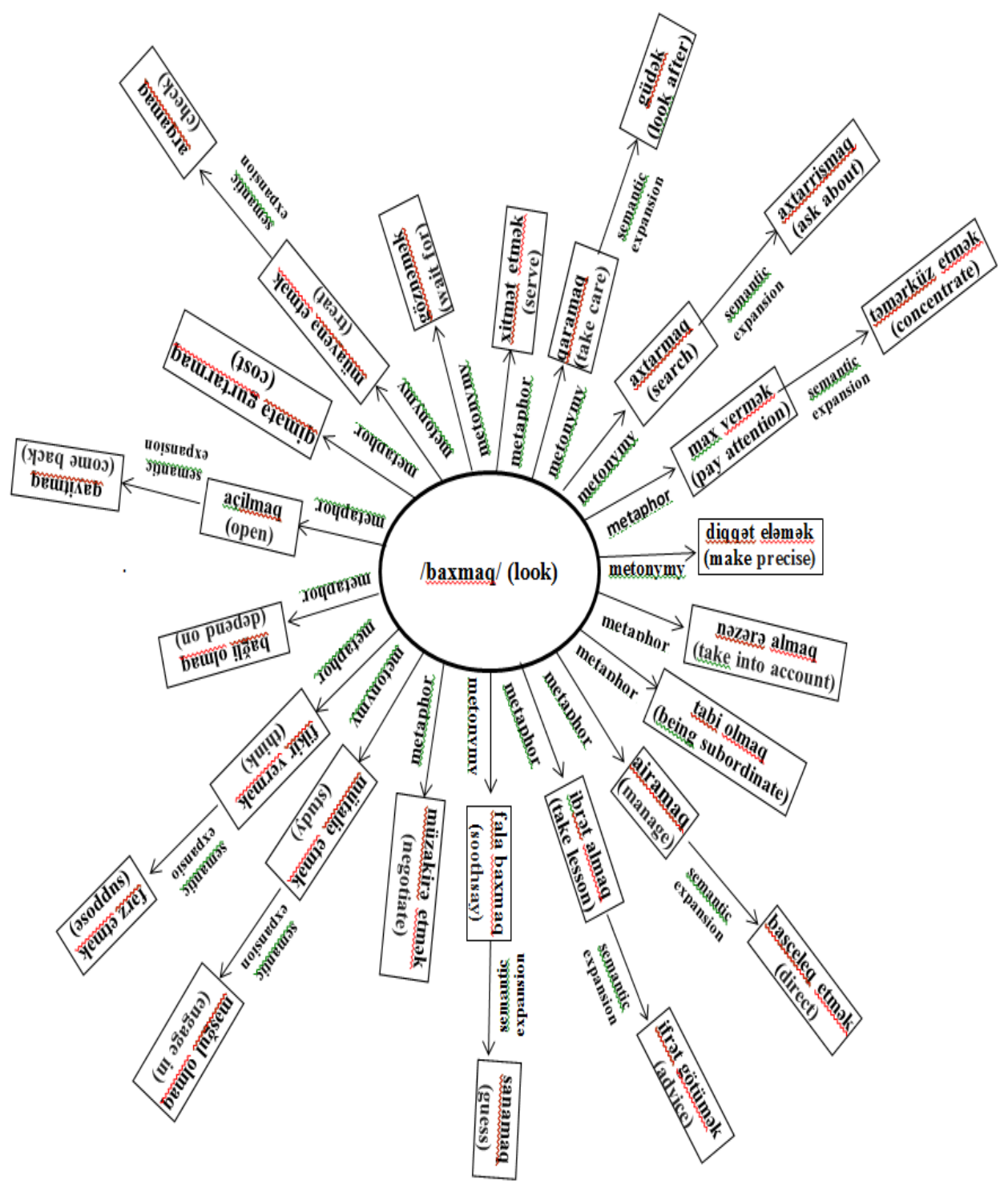

With regard to the diagram which is illustrated above, it can be argued that since in the following senses there is only one active mental area between the visual verb /baxmaq/ (look) and its senses, metonymy is the cognitive mechanism which has a role to play in this regard. These senses include qaramaq (take care), müayenə etmək (treat), axtarmaq (search), mütaliə etmək (study), diqqət eləmək (make precise), göznəmək (wait for) and fala baxmaq (soothsay). In addition, due to the fact that there are two mental areas present between the verb /baxmaq/ (look) and its senses in the following senses, the cognitive mechanism which has a role to play in this regard is metaphor. Theses senses include /xitmət etmək/ (serve), /müzakirə etmək/ (negotiate)/ /airamaq /(manage), /bağli olmaq/ (depend on),/ max vermək/ (pay attention), /nəzərə almaq/ (take into account), /fikir vermək/ (think), /ibrət almaq/ (take lesson), /açilmaq/ (open), /tabi olmaq/ (being subordinate) and /qimətə gurtarmaq/ (cost). Therefore, it can be inferred that polysemy is a systematic phenomenon and the meaning of the visual verb /baxmaq/ (look) in Azerbaijani Turkish which can be considered as the prototype is related to its other meanings through cognitive mechanism, particularly, metaphor and metonymy. This phenomenon leads to semantic expansion an finally the polysemy of the verb in Azerbaijani Turkish and in this way the extensive meaning network of the visual verb /baxmaq/ (look) is shaped which is explained based on the prototype and its relation to other members through family resemblances. Additionally, considering the prototype categorization, the visual verb /baxmaq/ (look) is more central in comparison to others which are more marginal. 


\section{Conclusion}

Metaphor and polysemy have been very important in the field of cognitive semantics. Words usually have more than one meaning and when these meanings are related to each other, this phenomenon is called polysemy. Metaphor refers to the relationship between two semantic areas in which one semantic area is expressed through another; in other words, in metaphor an abstract concept is experienced and understood based on a tangible concept. The present study which was conducted according to the polysemy and metaphorical status of the visual verb /baxmaq/ (look)) had some findings and implications. The findings revealed that for the visual verb /baxmaq/ (look) there are 140 usages and 19 senses, and a prototype and 18 peripheral meanings are presented after the categorization and abstraction of contextual types. qaramaq (take care), müayenə etmək (treat), axtarmaq (search), mütaliə etmək (study), diqqət eləmək (make precise), göznəmək (wait for), fala baxmaq(soothsay), /xitmət etmək/ (serve), /müzakirə etmək/ (negotiate)/,/ airamaq/ (manage), /bağli olmaq/ (depend on),/ max vermək/ (pay attention), /nəzərə almaq/ (take into account), /fikir vermək/ (think), /ibrət almaq/ (take lesson), /açilmaq/ (open), /tabi olmaq/ (being subordinate) and /qimətə gurtarmaq/ (cost). They further, demonstrated that polysemy is a systematic phenomenon and such elements like metaphor and metonymy are involved in its formation and description which leads to the verb's semantic expansion and finally its polysemy. On the other hand, in comparison to metonymy, metaphor has a more remarkable role in shaping polysemy and its application in various contexts. The findings also show that polysemy is not randomly and forms based on our experiences of different concepts and the meanings of words are different from each other because they are understood from different ways.

\section{References}

Allwood, J., \& Gardenfors, P. (1998). Cognitive semantics: Meaning and Cognition. Amsterdam: John Benjamin Publishing Company.

Evans, V., \& Melanie, G. (2006). Cognitive Linguistics: An Introduction. Edinburgh: Edinburgh University Press.

Fayyazi, M. (2008). The origin of metaphorical earnings in Persian in sense verbs from the perspective of cognitive semantics. Research literature, 8(2), 87-110.

Ibarretxe-Antunano, I. (1999). Polysemy and metaphor in perception verbs: A cross-linguistic study. Edinburgh: University of Edinburgh.

Lakoff, G. (1980a). The Contemporary of Metaphor. Chicago: The University of Chicago Press.

Lakoff, G. (1980b). The Invariance Hypothesis: Is abstract reason based on image schemas? Cognitive Linguistics. Cambridge: Cambridge University Press.

Lakoff, G., \& Johnson, M. (1980). Metaphor We Live By. Chicago: University of Chicago Press.

Lakoff, G., \& Johnson, M. (2003). Metaphors We Live BY. London: University of Chicago Press.

Mousavi, H. et al. (2014). Investigating the visual verb "Seeing" from a semantic point of view. Language Discussions, 5(2), 81-102. http://dx.doi.org/10.7208/chicago/9780226470993.001.0001

Nechybova, B. (2008). Conceptual Metaphors: From seeing to Understanding. Czech Republic: Masaryk University.

Pour Ebrahim, H. et al. (2012). Investigating of the Concept of Insight in the Qur'an in framework of cognitive semantics. Researches linguistics, 2(3), 3-19.

Sgöstrom, S. (1998). From vision to cognition: A Study of metaphor and Polysemy in Swedish. Department of Linguistics, Göteborg University, Göteborg.

Sharifi, L. (2009). A cognitive approach to a polysemous Persian verb. Innovations in Cognitive Sciences, 4(11), $1-11$.

Soltani Kofrani, R. (2012). A cognitive approach to motion verbs' polysemy in Persian. Unpublished master's thesis. Isfahan: Isfahan University.

Sweetser, E. (1990). From Etymology to Pragmatics. Cambridge Studies in Linguistics. Cambridge University Press. http://dx.doi.org/10.1017/CBO9780511620904

Taylor, J. (1995). Linguistic categorization: prototype in linguistic theory. Oxford: Oxford Clarendon Press.

Viberg, A. (1981). Polysemy and Differentiation in the Lexicon: Verbs of Physical Contact in Swedish. Department of Linguistics, Lund University.

Yousefi Rad, F. (2008). Investigating of Prepositions in Persian in framework of cognitive semantics. Tehran: 
Tarbiyat University Press.

\section{Appendix}

\begin{tabular}{|c|c|c|}
\hline \multicolumn{3}{|c|}{ Table of vowels of Azerbaijani Turkish } \\
\hline Phonetic mark & Turkish example & English meaning \\
\hline a & at & horse \\
\hline o & ot & fire \\
\hline$\ddot{\mathbf{u}}$ & üzüm & grape \\
\hline $\mathbf{u}$ & ulduz & star \\
\hline$\ddot{\mathbf{o}}$ & olke & land \\
\hline e & ev & house \\
\hline i & is & work \\
\hline ii & gis & winter \\
\hline a & 21 & hand \\
\hline \multicolumn{3}{|c|}{ Table of consonants of Azerbaijani Turkish } \\
\hline Phonetic mark & Turkish example & English meaning \\
\hline $\mathbf{b}$ & bas & head \\
\hline $\mathbf{p}$ & paltar & cloth \\
\hline $\mathbf{t}$ & talan & loot \\
\hline c & calamag & pour \\
\hline c & çngəl & spoon \\
\hline $\mathbf{x}$ & xama & cream \\
\hline d & darag & $\mathrm{comb}$ \\
\hline $\mathbf{r}$ & $r \partial f$ & niche \\
\hline $\mathbf{z}$ & zomi & farm \\
\hline $\mathbf{j}$ & jel & gels \\
\hline s & saimag & count \\
\hline $\mathbf{s}$ & şalvar & trousers \\
\hline 莺 & ğdomag & bear \\
\hline $\mathbf{f}$ & fisga & whistle \\
\hline $\mathbf{q}$ & gabag & pumpkin \\
\hline $\mathbf{k}$ & korvan & caravan \\
\hline $\mathrm{g}$ & görmok & see \\
\hline 1 & 21 & hand \\
\hline $\mathbf{m}$ & matah & goods \\
\hline $\mathbf{n}$ & nail & story \\
\hline $\mathbf{h}$ & hamar & smooth \\
\hline $\mathbf{v}$ & vermok & give \\
\hline$y$ & yatmag & sleep \\
\hline
\end{tabular}

\section{Copyrights}

Copyright for this article is retained by the author(s), with first publication rights granted to the journal.

This is an open-access article distributed under the terms and conditions of the Creative Commons Attribution license (http://creativecommons.org/licenses/by/4.0/). 